\title{
PARAFRASA LEGENDA “TUAK (AREN)" MENJADI NASKAH DRAMA SEBAGAI BAHAN AJAR DI SMA
}

\author{
Ira Aprillah Siringo-Ringo', Kasih Kristina Waruwu², Putri Khairani ${ }^{3}$, Dian Syahfitri, \\ S.S., M.Hum ${ }^{4}$ \\ e-mail: ${ }^{1}$ iraaprillah99@gmail.com, ${ }^{2}$ kasihkristinawaruwu99@gmail.com, \\ ${ }^{3}$ putrikhairani791@gmail.com, ${ }^{4}$ diansyahfitri@unprimdn.ac.id
}

\begin{abstract}
ABSTRAK
Penelitian ini membahas mengenai penentuan unsur intrinsik dan ekstrinsik serta memarafrasakan legenda "Tuak (Aren)" menjadi naskah drama sebagai bahan ajar di SMA. Penelitian ini menggunakan metode deskriptif kualitatif yang bertujuan mendeskripsikan secara sistematis dan akurat dengan menggunakan kata-kata atau kalimat. Teknik pengumpulan data menggunakan teknik dokumen berupa teks tertulis. Data dalam penelitian ini adalah berupa dokumen literal yang diambil dari Indonesia dokumen berisi kumpulan legenda-legenda Nusantara. Sumber data dalam penelitian ini adalah sumber data sekunder karena diperoleh dengan cara membaca, mempelajari dan memahami melalui media lain yang bersumber dari literatur, buku-buku, jurnal, serta dokumen. Hasil penelitian diketahui legenda "Tuak (Aren)" terbentuk karena adanya kepercayaan masyarakat di Samosir terhadap pohon aren. Sehingga dahulu orang yang ingin mengambil hasil dari pohon aren harus memohon terlebih dahulu untuk mengambilnya dan dapat bermanfaat untuk kehidupannya. Cerita tersebut terus melegenda hingga ditulis dalam sebuah dokumen. Legenda yang telah disusun kemudian diparafrasakan oleh peneliti menjadi naskah drama untuk dijadikan sebagai bahan ajar Bahasa Indonesia.
\end{abstract}

Kata Kunci: Parafrasa, Legenda “Tuak (Aren)”, Naskah Drama.

\section{A. PENDAHULUAN}

Cerita rakyat membantu masyarakat untuk mengenal asal-mula tradisi kebudayaan yang dimilikinya dan diwariskan secara turun-temurun agar dapat dilestarikan di masa yang akan datang. Ketika mengenal cerita rakyat di suatu daerah maka akan mengenal budaya yang ada di daerah tersebut. Cerita rakyat yang ada di setiap daerah dapat dikenal dalam bentuk tradisi 
lisan maupun dalam bentuk tertulis. Masing-masing daerah memiliki cerita rakyat tersendiri. Salah satunya cerita di daerah Sumatra Utara.

Daerah Sumatra Utara memiliki beragam cerita, di antaranya legenda "Asal Mula Terjadinya Danau Toba". Namun, legenda "Tuak (Aren)" tidak sepopuler legenda tersebut. Legenda "Tuak (Aren)" mengisahkan sepasang suami-istri bersama dua orang anaknya. Anak laki-lakinya bernama Tare Iluh dan yang kedua, anak perempuan bernama Sibou. Sang suami sebagai kepala keluarga akhirnya meninggal dunia setelah mengalami sakit. Sang istri menjadi tulang punggung keluarga dan berusaha keras menghidupi kedua anaknya. Sebab, bekerja keras membuatnya jatuh sakit hingga meninggal dunia. Tare Iluh dan Sibou menjadi anak yatim piatu. Kemudian diasuh oleh bibi mereka. Tare Iluh pun tumbuh menjadi pria dewasa yang gagah, sedangkan adiknya Sibou tumbuh menjadi gadis yang cantik. Tare Iluh pergi merantau untuk mencari uang agar tidak menjadi beban bagi bibinya. Setelah di perantauan, Tare Iluh memiliki banyak utang karena bermain judi. Akibatnya Tare Iluh dipasung oleh penduduk setempat. Berita itu terdengar ke telinga Sibou dan akhirnya dia mencari keberadaan Tare Iluh. Suatu ketika Sibou bertemu dengan kakek tua dan bertanya tentang keberadaan Tare Iluh. Lalu kakek tua itu pun menyarankan Sibou untuk memanjat pohon yang paling tinggi sambil memanggil-manggil nama Tare Iluh. Tanpa berpikir panjang Sibou menjalankan saran seperti yang dikatakan kakek tua itu. Namun, tidak membuahkan hasil. Akhirnya Sibou menjadi putus asa dan berdoa kepada Tuhan Yang Maha Kuasa untuk merelakan air mata, rambut dan seluruh anggota tubuhnya untuk dimanfaatkan sebagai kepentingan penduduk. Tidak lama kemudian tubuhnya berubah menjadi pohon aren yang dapat menghasilkan kolang-kaling sebagai bahan makanan, air mata Sibou berubah menjadi tuak (nira) yang dijadikan minuman oleh penduduk. Sedangkan rambutnya digunakan untuk membuat atap rumah. Cerita ini kemudian menjadi sebuah legenda asal mula munculnya "Tuak (Aren)". Legenda ini secara perlahan menjadi dilupakan oleh masyarakat, sehingga peneliti akan memarafrasakan legenda ini ke dalam bentuk naskah drama sebagai bahan ajar agar peserta didik dapat mengetahui dan menggambarkan bagaimana cerita legenda tersebut. Memarafrasakan sebuah cerita ke dalam bentuk lain tidak semudah yang dibayangkan.

Menurut OWL Purdue (dalam Usman, 2015) parafrasa didefinisikan sebagai (1) kemampuan seseorang dalam menulis ulang ide atau gagasan orang lain dengan kata-kata sendiri dan ditampilkan dalam bentuk yang baru. (2) merupakan cara yang terstruktur dan sah dalam meminjam sendiri dan ditampilkan dalam bentuk yang baru. (3) sebuah pernyataan ulang yang lebih lengkap, detail, dan mudah dipahami dibandingkan dalam sebuah ringkasan. 
Pendekatan parafrasa adalah pemahaman suatu makna yang ada dalam cerita dengan mengungkapkan kembali isi gagasan yang disampaikan oleh pengarang menggunakan katakata maupun kalimat yang berbeda. Tujuan dari pendekatan parafrasa ini adalah untuk menyederhanakan pemakaian kata-kata yang secara detail agar lebih mudah dipahami. Oleh sebab itu, parafrasa adalah istilah linguistik yang mengungkapkan kembali suatu konsep dengan cara yang berbeda dari bentuk sebelumnya tanpa mengubah makna yang sesungguhnya. Hal ini dimaksudkan untuk menggunakan kata-kata sendiri dalam mengungkapkan ide yang sama ke dalam bentuk yang berbeda, tetapi dengan tujuan yang sama. Selain membuat gagasan yang baru memarafrasakan sebuah tulisan juga digunakan untuk menjaga koherensi maupun keutuhan alur cerita. Dari cerita yang diparafrasakan ke dalam bentuk naskah drama bertujuan agar legenda "Tuak (Aren)" dapat diketahui secara jelas oleh siapa pun yang membacanya.

Naskah drama sebagai karya sastra juga harus mampu memiliki nilai manfaat dan keindahan yang tidak dapat dipisahkan dengan pengajaran bahasa dan sastra karena keduanya saling membangun, terutama dalam pengajaran bahasa selalu menggunakan karya sastra sebagai objek utamanya dalam menjelaskan fungsi dan ciri bahasa tersebut (Noermanzah dalam Lasmiyanti, dkk, 2019). Naskah drama disusun berdasarkan unsur-unsur intrinsik yang membangun. Unsur-unsur pembangun naskah drama di antaranya tema, latar, alur, tokoh dan penokohan serta amanat.

\section{B. KAJIAN TEORI}

\section{Parafrasa}

Untuk membantu siswa dalam memahami legenda tersebut, maka digunakan pendekatan parafrasa. Hal ini sejalan dengan pendapat Aminuddin (dalam Nuratni, dkk, 2014) bahwa pendekatan parafrasa adalah strategi pemahaman kandungan makna dalam cipta sastra dengan jalan mengungkapkan kembali gagasan yang disampaikan pengarang dengan menggunakan kata-kata dan kalimat yang digunakan oleh pengarangnya. Tujuannya yaitu untuk menyederhanakan pemakaian kata atau kalimat seorang pengarang, sehingga pembaca lebih mudah memahami kandungan makna yang terdapat dalam suatu cipta karya sastra. Memarafrasakan sebuah karya sastra bukanlah hal yang mudah. Bila salah tafsir, maka terjadi kesalahan makna yang sesungguhnya. 
Menurut Kridalaksana langkah-langkah membuat parafrasa (1) mengartikan kata yang sulit, (2) mengartikan kata yang sengaja dihilangkan penulisnya, (3) menambah tanda baca, dan (4) menyusun dalam bentuk kalimat yang membentuk paragraf, (5) membaca teks keseluruhan. Selanjutnya adalah langkah memarafrasakan legenda menjadi naskah drama dengan cara (1) membaca keseluruhan teks legenda dengan seksama, (2) memahami isi cerita legenda secara utuh, (3) menjelaskan kata-kata perumpamaan atau ungkapan yang terdapat dalam legenda, (4) menguraikan kembali isi legenda secara tertulis ke dalam bentuk naskah drama menggunakan kalimat sendiri, (5) menyampaikan secara lisan atau dipraktikkan. Untuk menyusun alur cerita pada naskah drama, penulis perlu mengetahui jalan cerita dan menemukan gagasan pokok pada kalimat utamanya. Kalimat disusun secara sederhana agar mudah dipahami.

\section{Legenda}

Cerita rakyat yang melatarbelakangi munculnya penamaan suatu tempat termasuk ke dalam kategori legenda. Legenda adalah dongeng yang berhubungan dengan peristiwa sejarah atau suatu kejadian alam yang di dalamnya termasuk unsur-unsur fantasi, seperti munculnya suatu nama tempat atau bentuk topografi suatu daerah (Sugiarto dalam Suwarno, dkk, 2018). Terkait dengan hal itu, kehadiran legenda dapat memberi dedikasi yang berarti bagi masyarakat. Oleh sebab itu, penulisan legenda juga dapat diubah dalam bentuk karya sastra lain, salah satunya naskah drama. Hal ini disebut dengan parafrasa.

Memarafrasakan Legenda "Tuak (Aren)" dalam bentuk naskah drama diharapkan sebagai cara penyebarluasan legenda dengan cepat. Selain itu, hasil parafrasa legenda "Tuak (Aren)" dapat dijadikan sebagai bahan ajar. Berdasarkan latar belakang yang telah dipaparkan di atas, dapat disimpulkan akhir dari sebuah penelitian ini berupa memarafrasakan legenda “Tuak (Aren)” menjadi naskah drama sebagai bahan ajar.

\section{Naskah Drama}

Naskah drama merupakan suatu karya yang berisi percakapan. Dari percakapan inilah pemeran dalam sebuah drama mendapatkan dialog dan peran yang akan dimainkannya. Drama memiliki kesejajaran dengan sastra lain seperti puisi dan prosa. Naskah drama memiliki bentuk sendiri yang ditulis dalam bentuk dialog yang didasarkan atas konflik batin dan mempunyai kemungkinan dipentaskan (Waluyo dalam Lasmiyanti Arie, dkk, 2019). Untuk mencapai penulisan naskah drama sesuai dengan konsepnya, maka perlu adanya keselarasan dengan alur cerita legenda agar tidak terjadi kesenjangan makna. 
Makna yang terkandung dalam naskah drama merupakan bentuk nilai-nilai kemasyarakatan. Sejalan dalam hal itu, mengungkapkan hal kehidupan manusia dan juga memberi manfaat untuk mengingat kejadian-kejadian di masa lampau sebagai bentuk apresiasi sejarah.

\section{METODE PENELITIAN}

Metode penelitian ini berupa metode penelitian kualitatif. Penelitian kualitatif suatu penelitian yang mencari makna, pemahaman, pengertian tentang suatu fenomena, kejadian, maupun kehidupan manusia dengan terlibat langsung atau tidak langsung dalam setting yang diteliti, kontekstual, dan menyeluruh. Pendekatan kualitatif diharapkan mampu menguraikan secara lebih detail dan mendalam tentang tulisan dan dikaji dari sudut pandang yang utuh dan komprehensif.

Penelitian kualitatif merupakan suatu strategi inquiri yang menekankan pencarian makna, pengertian, konsep, karakteristik, simbol, maupun deskripsi tentang suatu fenomena; fokus dan multimetode, bersifat alami dan holistik; mengutamakan kualitas, menggunakan beberapa cara, serta disajikan secara naratif (Yusuf, A. Muri: 329). Dokumen berupa catatan atau karya seseorang yang sudah berlalu. Dokumen tersebut dapat dijadikan informasi yang berguna untuk kepentingan penelitian kualitatif.

Penelitian ini menggunakan metode penelitian deskriptif kualitatif yang disajikan dalam bentuk deskriptif atau naratif. Penelitian ini bersumber dari data yang dikumpulkan berupa kata-kata, kalimat, wacana, dan bukan berupa angka. Untuk memberikan gambaran penelitian, para peneliti lebih banyak mengambil berbagai kutipan data berupa hasil pengamatan, analisis dan pemanfaatan dokumen yang sudah ada.

Sumber data penelitian merupakan suatu sumber informasi atau data yang diperoleh sebagai bahan subjek yang akan diteliti. Menurut Sugiono (dalam Herviani dan Febriansyah, 2016) sumber data sekunder adalah sumber data yang diperoleh dengan cara membaca, mempelajari dan memahami melalui media lain yang bersumber dari literatur, buku-buku serta dokumen. Penulis akan meneliti dokumen literal yang diambil dari Indonesia dokumen berisi kumpulan legenda-legenda Nusantara. Dokumen Legenda "Tuak (Aren)" adalah bahan yang analisis oleh peneliti dan memarafrasakan cerita tersebut ke dalam bentuk naskah drama. 
Dokumen merupakan suatu karya seseorang berupa catatan tentang sesuatu yang sudah berlalu. Dokumen dapat berupa teks tertulis, gambar, maupun foto. Dokumen yang dianalisis peneliti berupa cerita (legenda), dengan mengkaji unsur intrinsik dan ekstrinsiknya. Dari dokumen yang dikaji, peneliti akan mengungkap kembali cerita yang sama dalam bentuk yang berbeda disebut sebagai parafrasa.

Metode pendekatan deskriptif kualitatif merupakan metode pengolahan data dengan cara menganalisis faktor-faktor yang berkaitan dengan objek penelitian melalui penyajian data secara lebih mendalam. Penelitian deskriptif yaitu mengumpulkan data berdasarkan faktor-faktor yang menjadi pendukung terhadap objek penelitian, kemudian menganalisis setiap faktor dan menentukan peranannya (Arikunto dalam Prabowo dan Heriyanto, 2013).

Peneliti menggunakan metode deskriptif kualitatif untuk menganalisis data. Data yang telah diperoleh dari dokumen kemudian akan dideskripsikan unsur-unsur intrinsik dan ekstrinsik cerita legenda sebagai jawaban dari permasalahan yang ada. Sesudah tahap analisis, peneliti akan melakukan pengubahan bentuk cerita dengan memarafrasakan menjadi naskah drama.

\section{HASIL DAN PEMBAHASAN}

\section{Unsur Intrinsik Drama dalam Legenda Tuak (Aren)}

1. Tema: Pengorbanan untuk menebus kesalahan

2. Tokoh dan Penokohan

Dalam legenda Tuak (Aren) terdapat beberapa tokoh dan penokohannya, antara lain:

1. Inang (Ibu) : sabar dan tegar

2. Bibi : sabar, penyayang dan lemah lembut

3. Tare Iluh : egois, suka bermalas-malasan dan meresahkan masyarakat

4. Beru Sibou : baik, penurut, dan mau melakukan apapun untuk bisa bertemu dengan abangnya

5. Kakek : sebagai sosok yang bijak dan pemberi nasehat

6. Orang Ladang : baik hati dan jujur

3. Alur (Plot) 
Cerita ini menggunakan alur maju karena menceritakan dari awal Tare Iluh dan Beru Sibou masih kecil hingga dewasa, hingga peristiwa besar terjadi yang menyebabkan Tare Iluh dipasung dan adiknya Beru Sibou mengorbankan dirinya menjadi pohon aren.

4. Latar (Setting)

a) Latar tempat: Sebuah desa, tanah Karo, Sumatra Utara, negeri orang (daerah perantauan)

b) Latar suasana: Memprihatinkan, sedih, kecewa, menegangkan, haru

c) Latar waktu: Zaman dahulu, berhari-hari, berbulan-bulan, bertahun-tahun

5. Sudut Pandang

Sudut pandang yang digunakan penulis di dalam cerita ini merupakan sudut pandang orang ke tiga. Di mana penulis mencerikan tokoh dengan menyebut nama orang, atau penulis hanya sebagai pengamat tidak melibatkan dirinya sebagai tokoh utama di dalam cerita itu.

6. Gaya Bahasa

Gaya bahasa yang digunakan penulis dalam cerita ini adalah gaya bahasa penegasan berupa klimaks, pada bagian paragraf pertama ia memaparkan "di sebuah desa, di tanah Karo, Sumatra Utara" menyatakan hal secara berturut-turut yang semakin lama-makin tinggi tingkatannya. Gaya bahasa lain yang terdapat dalam cerita ini adalah gaya bahasa hiperbola, melebih-lebihkan seperti air matanya menjelma tuak. Bahasa yang digunakan penulis mudah dipahami dan dimengerti oleh pembaca.

7. Amanat

Amanat yang terdapat dalam cerita ini adalah jika ditinggalkan kedua orang tua dan menjadi anak yatim piatu sebaiknya merantaulah dengan mencari pekerjaan yang baik dan tidak mengikuti pergaulan buruk. Jika ingin berkorban, jadilah korban yang bermanfaat untuk orang banyak tanpa merisaukan orang terdekat.

\section{Unsur Ekstrinsik Drama dalam Legenda Tuak (Aren)}

1. Nilai Budaya 
Adat istiadat/kebiasaan masyarakat di daerah Samosir dalam mengambil nira/tuak dari pohon aren sebagai lambang minuman tradisional suku Batak. Selain sebagai minuman sehari-hari, tuak juga memiliki fungsi yang sangat penting dalam kehidupan sosial-budaya bagi masyarakat di daerah Samosir. Dalam tardisi suku Batak, nira/tuak juga digunakan pada upacara-upacara tertentu, seperti upacara manиап отри-отри dan manulangi.

2. Nilai Agama dan Kepercayaan

Adanya kepercayaan bahwa legenda Tuak (Aren) merupakan wujud jelmaan dari seorang wanita yang merelakan tubuhnya untuk dimanfaatkan bagi masyarakat seperti ijuk, nira, dan buahnya yaitu kolang-kaling. Sebagian masyarakat setempat saat mengambil air nira dari pohon aren, mereka menyanyikan lagu khusus untuk wanita yang dipercayai menjadi pohon aren.

\section{Nilai Sosial}

Kondisi sosial masyarakat di daerah Samosir umumnya mendapatkan uang dari hasil pertanian. Di antaranya mereka banyak memanfaatkan pohon aren dengan cara menyadap untuk menghasilkan nira, kemudian mengolahnya menjadi tuak. Hal tersebut menjadi kepuasan bagi mereka. Tetapi penyadap nira tidak sembarangan orang karena banyak ritual yang harus dilakukan sebelum melakukan proses penyadapan.

\section{Nilai Moral}

Nilai moral yang dapat kita lihat yaitu adanya ikatan saudara untuk saling tolong menolong dalam keadaan susah. Keadaan tersebut juga berjalan dengan baik tanpa ada rasa pamrih.

\section{Kondisi Ekonomi}

Masyarakat selalu ingin mengubah pola hidupnya melalui ekonomi dengan memanfaatkan pohon aren. Ijuknya dapat dijadikan sapu, atap rumah. Buahnya menjadi kolang-kaling, airnya dapat diolah menjadi tuak dan gula aren. Dengan demikian, masyarakat di daerah Samosir dapat menjualnya dan hasil dari pohon aren tersebut dapat membantu menambah penghasilan.

\section{Naskah Drama Tuak (Aren)}

\section{PELAKON:}


1. Inang

2. Bibi

3. Tare Iluh

4. Beru Sibou

5. Kakek

6. Orang Ladang

Pada zaman dahulu kala hiduplah sebuah keluarga yang terdiri dari suami istri dan dua orang anaknya. Anak pertama seorang laki-laki yang bernama Tare Iluh dan kedua perempuan yang bernama Beru Sibou. Mereka tinggal di sebuah desa yang terletak di Tanah Karo, Sumatra Utara. Tare Iluh dan Beru Sibou adalah anak yang patuh terhadap kedua orang tuanya. Ketika di rumah Inang menyuruh mereka membersihkan rumah sedangkan Bapak sedang tidur di kamar karena keadaan yang kurang sehat.

\section{(Adegan 1)}

Inang : "Bang, bersihkan dulu rumput di depan rumah kita. Sudah banyak kali itu rumputnya kayak hutan!”

Tare Iluh : "Iya, Inang” (bergegas mengambil cangkul)

Inang : "Dek, sapukan rumah itu biar bersih, mau keluar dulu Inang sebentar ke ladang"

Beru Sibou : "Baik, Inang” (bergegas mengambil sapu)

Kemudian, mereka mengerjakan apa yang diperintah oleh Ibunya. Saling bekerja sama adalah cara yang tepat untuk menyelesaikan pekerjaan. Tanpa sengaja, Beru Sibou mendengar suara Bapak dari kamar memanggil-manggil. Melihat keadaan Bapak yang sangat lemah dan wajahnya begitu pucat. Pada akhirnya, Bapak pun mengembuskan napas terakhirnya.

Sepeninggal suaminya, sang istri lah yang harus bekerja keras membanting tulang setiap hari untuk menghidupi kedua anaknya yang masih kecil. Wanita itu pun jatuh sakit dan akhirnya meninggal dunia. Untungnya, orang tua mereka masih memiliki sanak saudara dekat. Maka sejak itu, Tare Iluh dan adiknya diasuh oleh bibinya yaitu adik dari ayah mereka. (Adegan 2) 
Waktu terus berjalan. Tare Iluh pun tumbuh menjadi pemuda yang gagah sedangkan Beru Sibou tumbuh menjadi gadis remaja yang cantik. Sebagai seorang pemuda, tentunya Tare Iluh sudah mulai berpikir dewasa. Ia memutuskan pergi merantau untuk mencari uang dari hasil keringatnya sendiri karena ia tidak ingin selalu menjadi beban bagi orang tua asuhnya.

Tare Iluh : "Adekku, Beru kemarilah.”

Beru Sibou : “Ada apa, Bang?” (Beru, datang dan duduk mendengar abangnya)

Tare Iluh : "Dek, kita sudah lama diasuh oleh bibi, kita sekarang sudah dewasa. Abang mau merantau, untuk mengubah nasib kita."

Beru Sibou : "Tapi, bagaimana dengan aku, Bang?"

Tare Iluh : : "Tenang saja, kamu di sini saja menemani Bibi. Nanti kalau uang Abang sudah banyak, Abang pasti cepat kembali ke sini.”

Beru Sibou : "Tapi Abang jangan lupa kembali kalau sudah berhasil.”

Tare Iluh : "Tentu, Dek.”

Keesokan harinya, setelah pamit dengan bibi dan Beru, Tare Iluh berangkat merantau ke negeri orang. Sepeninggal abangnya, Beru Sibou sangat sedih ia merasa telah kehilangan segalanya.

\section{(Adegan 3)}

Di kampung, Beru dikagetkan dengan seseorang yang membawa kabar tentang Tare Iluh, bahwa abangnya Tare Iluh dipasung oleh masyarakat setempat. Beru menangis tersedusedu. Esok harinya, Beru Sibou mempersiapkan semua peralatan dan sedikit bekal. Ia akan pergi menemui abangnya dan membawa beberapa uang untuk melunasi utang abangnya nanti. Ia tak putus asa dan terus melanjutkan perjalanannya. Bajunya sudah sangat kotor dan bau. Bahkan orang mengira gila. Suatu ketika ia bertemu dengan kakek-kakek yang sudah beruban dan sangat renta usinya.

Beru Sibou : "Selamat sore, Kek!"

Kakek : :Selamat sore cucuku. Adakah yang bisa Kakek bantu?"

Beru Sibou : "Apakah Kakek pernah bertemu dengan Abang saya?”

Kakek : "Siapakah nama Abangmu, Cu? Barang kali Kakek bisa membantu." 
Beru Sibou : “Tare Iluh Kek!” (Beru Sibou sangat berharap, kali ini ia bisa menemukan jejak abangnya)

Kakek : "Tare Iluh? Maaf cucuku. Kakek tidak pernah bertemu dengan Abangmu. Tapi sepertinya Kakek pernah mendengar namanya. Pemuda itu sangat terkenal bermain judi."

Beru sibou : "Benar, Kek. Aku mendapat kabar seperti itu. Di manakah negeri itu berada, Kek? Aku ingin ke sana menemui Abangku."

Kakek : "Maaf, cucuku. Kakek juga tidak tahu di mana letak negeri itu. tapi Kakek ingin menyarankan sesuatu."

Beru Sibou :"Saran apakah itu, Kek?"

Kakek : "Panjatlah sebuah pohon yang tinggi. Setelah sampai pada puncaknya, bernyanyilah sambil memanggil nama Abangmu. Barangkali ia bisa mendengarnya."

Beru Sibou : :"Terima kasih, Kek."

\section{(Adegan 4)}

Setelah percakapan mereka selesai. Kakek itu pergi dan Beru Sibou mencari pohon yang tinggi ke arah bukit. Di sana ia menemui pohon yang tinggi dan memanjatnya hingga ke puncak. Ia bernyanyi dan berteriak memanggil nama Tare Iluh. Saat itu, seseorang mendengar tapi bukan abangnya melainkan orang yang sedang pergi ke ladang.

Orang Ladang : "Heh.... Kau sedang apa di sana. Kenapa kau berteriak seperti orang gila. Turunlah. Kau bisa saja jatuh dari sana."

Beru Sibou : "Aku sedang memanggil Abangku. Barang kali ia bisa mendengar ketika aku memanggil namanya di atas pohon yang tinggi ini."

Orang ladang : : "Tidak mungkin itu terjadi. Orang yang lebih dekat saja tidak mendengar. Bagaimana Abangmu bisa mendengarnya sedangkan ia berada di tempat jauh."

Beru Sibou : : "Aku percaya, Abangku bisa mendengarnya."

Karena Beru Sibou tidak mendengar ucapan orang ladang itu, akhirnya ia pun ditinggalkan di tempat itu. Beru Sibou tetap percaya dan yakin bahwa abangnya akan 
mendengar suaranya. Sehingga ia terus memanggil-manggil berulang kali bahkan berjam-jam lamanya.

\section{(Adegan 5)}

Hingga sampai pada sore hari sebelum matahari terbenam. Beru Sibou bernyanyi dengan nada suara yang sangat memelas. Akhirnya ia segera mengangkat kedua tangannya dan berdoa kepada Tuhan.

Beru Sibou : "Ya Tuhan! Tolonglah hambamu ini. Aku bersedia melunasi semua utang abangku dan merelakan air mata, rambut dan seluruh anggota tubuhku dimanfaatkan untuk kepentingan penduduk negeri ini, terutama penduduk kampung yang memasung abangku."

Ketika Beru Sibou mengucapkan kalimat itu, tiba-tiba angin bertiup kencang, langit menjadi mendung. Pohon yang dipanjati Beru Sibou diguncang angin kencang dan hujan deras turun diikuti suara guntur yang menggelegar. Tiba-tiba tubuh Beru Sibou menjadi keras dan kini menjelma menjadi sebuah pohon aren. Air matanya berubah menjadi tuak atau nira yang berguna sebagai minuman. Rambutnya menjadi ijuk yang dapat dimanfaatkan untuk atap rumah. Tubuhnya menjelma pohon aren.

\section{E. SIMPULAN DAN SARAN}

Berdasarkan hasil penelitian yang telah dipaparkan pada bab sebelumnya, dapat disimpulkan bahwa legenda "Tuak (Aren)" memberikan nilai-nilai moral yang mendidik. Peneliti telah menguraikan unsur-unsur intrinsik dan ekstrinsik yang terdapat pada legenda tersebut. Unsur intrinsik merupakan unsur pembentuk drama dari dalam cerita yang terdiri dari tema, tokoh dan penokohan, alur (plot), latar (setting), sudut pandang, gaya bahasa, amanat. Sedangkan unsur ekstrinsik menjelaskan tentang unsur pembentuk dari luar cerita. Artinya, unsur ekstrinsik menyinggung tentang nilai seperti nilai budaya, nilai agama dan kepercayaan, nilai sosial, nilai moral dan kondisi ekonomi.

Setelah menguraikan unsur-unsur pembangunnya, legenda "Tuak (Aren)" dapat diparafrasakan menjadi naskah drama. Di mana, drama legenda "Tuak (Aren) menceritakan tentang pengorbanan seorang adik untuk menebus kesalahan abangnya sehingga sang adik berubah menjadi pohon aren. Tujuan utama melakukan kegiatan ini adalah untuk membantu 
dan mempermudah siswa dalam mengingat legenda "Tuak (Aren)" serta melestarikan cerita daerah yang hampir terlupakan.

Berdasarkan hasil penelitian yang telah diperoleh, peneliti memberikan saran bahwa memaparkan unsur intrinsik dan ekstrinsik akan mempermudah untuk memahami isi dari sebuah cerita. Serta, hasil dari memarafrasakan legenda "Tuak (Aren)" menjadi naskah drama dapat dijadikan sebagai bahan ajar Bahasa Indonesia. Dengan demikian, dapat menjadi masukan pengembangan wawasan peserta didik.

\section{DAFTAR PUSTAKA}

Herviani, Febriansyah. 2016. Tinjauan Atas Proses Penyususnan Laporan Keuangan Pada Young Enterpreneur Academy Indonesia Bandung. Jurnal Riset Akuntansi, 8 (2), 1 17.

Kasyian. 2015. Kesalahan Implementasi Teknik Triangulasi Pada Uji Validitas Data Skripsi Mahasiswa Jurusan Pendidikan Seni Rupa FBS UNY. Imaji, 13 (1), 1 - 13

Lasmiyanti, Arie, dkk. 2019. Peningkatan Kemampuan Menulis Naskah Drama melalui Pendekatan Kontekstual Berbasis Cerita Rakyat Musi Rawas Siswa Kelas VIII SMP Negeri Pedang. Diksa: Pendidikan Bahasa dan Sastra Indonesia, 1 (5), 52 - 61

Nuratni, Ni Komang Rai, dkk. 2014. Kajian Puisi Akrostik dengan Pendekatan Parafrasa Untuk Meningkatkan Kemampuan Memahami Puisi Siswa Kelas VII.C Di SMP Negeri 7 Singaraja. Pendidikan Bahasa dan Sastra Indonesia, Undiksha, 2 (1), 1 - 11

Prabowo dan Heriyanto. 2013. Analisis Pemanfaatan Buku Elektronik (E-Book) Oleh Pemustaka Di Perpustakaan SMA Negeri 1 Semarang. Jurnal Ilmu Perpustakaan, 2 (2), $1-9$

Rahmat, Pupu Saeful. 2009. Penelitian Kualitatif. Equilibrium, 5 (9), 1 - 8

Sibarani, Robert. 2012. Kearifan Lokal Hakikat, Peran, Dan Metode Tradisi Lisan. Jakarta: Asosiasi Tradisi Lisan (ATL). 
Tarigan, Sri Fatimah. 2017. Kepercayaan Masyarakat Karo Terhadap Legenda Pohon Enau Di Desa Bukit Makmur: Pendekatan Antropologi Sastra. Departemen Sastra Indonesia. Universitas Sumater Utara.

Usman, Raja. 2015. Penggunaan Metode Parafrase untuk Meningkatkan Kemampuan Menulis Parafrase Puisi ke Prosa terhadap Hasil Belajar Siswa Kelas II SMP Al-Ittihat Pekan Baru. Sorot, 10 (2), 169 - 176

Yusuf A. Muri. 2014. Metode Penelitian Kuantitatif, Kualitatif dan Penelitian Gabungan. Jakarta: PT Fajar Interpratama Mandiri.

Nuratni, Ni Komang Rai, dkk. 2014. Kajian Puisi Akrostik dengan Pendekatan Parafrasa untuk Meningkatkan Kemampuan Memahami Puisi Siswa Kelas VII.C di SMP NEGERI 7 SINGA RAJA. Undiksha, I (2), 1 - 11

Suwarno, dkk. 2018.Sejarah, Unsur Kebudayaan, dan Nilai Pendidikan Karakter Dalam Legenda Sungai Naga. Retorika, 1 (2), 194 - 203 